\title{
The Methodological Problems of Filipino Philosophy
}

Roland Theuas DS. Pada

\begin{abstract}
The paper aims at outlining the problems and follies with the research involved in Filipino Philosophy by conducting a survey of the methodologies involved in the construction of "perspectives" and "ideologies" that constitute what Filipino philosophers want to establish as Filipino Philosophy. The main contention of this paper is that these methodologies either fall short from their use of ideas and concepts (i.e., phenomenology, linguistic constructivism, and weak anthropological data) or construct a mythos of Filipino Philosophy that is intended to construct an identity rather than depict a volksgeist that can be identified with Filipino consciousness. Likewise, I hypothesize that the idea of Filipino philosophy lacks historical rapport insofar as the work of Filipino philosophers fails to achieve legitimacy in philosophy through discursive and critical engagement with current philosophical discourses. At the end of the paper, I will propose two solutions that will address these problems. By following the works of F.P.A. Demeterio III and Florentino Hornedo, we can surmise an alternative method of discoursing through the notion of Filipino philosophy via critical engagement with socio-political critique of Philippine ideologies or via true anthropological methods.
\end{abstract}

Keywords: Filipino philosophy, ethnophilosophy, anthropological method, socio-political critique

\section{Introduction}

7 he problem of identifying a philosophical tradition as an intrinsic part of Filipino culture has been a growing trend since late 1950's. As to whether there is a tradition of philosophy that exists in the Philippines, scholars have mixed views regarding the nature of Filipino philosophy or its existence. Some scholars argue that the existence of Filipino philosophy is dependent upon the condition of thought and worldviews that are consistent in the behavior of people in the Philippines; this view is shared by the works

(c) 2014 Roland Theuas DS. Pada

http://www.kritike.org/journal/issue 14/pada june2014.pdf

ISSN 1908-7330

(cc) BY-NC 
of Mercado ${ }^{1}$ and Timbreza, ${ }^{2}$ whose analysis of language and folk-sayings insists that there is a common ground to which Filipino thought, as a Philosophy, can be observed. Other scholars insist that Filipino philosophy is the product of how Filipinos are able to engage in the discourse of philosophy through their own unique concerns and anxieties.

The analyses of scholars engaged in this discourse have a common contention that the history of philosophy, or more specifically academic philosophy, is rooted in the tradition that has been left by its colonizers and its continuing exposure to foreign theories and ideologies. Various historical and critical perspectives are offered by scholars regarding this view; one of the seminal perspectives in the history of philosophy in the Philippines comes from Cullum ${ }^{3}$ - he notes that the tradition of philosophy in the Philippines is marked by its connection with its colonizers, particularly that of Spain. ${ }^{4}$ Furthermore, Cullum remarks that the initial tradition of scholarship for philosophy in the Philippines revolved around the scholastic tradition of dividing the study of philosophy under logic, physics, and metaphysics. ${ }^{5}$ If we were to consider the age of this publication, the question of how it was possible that enlightenment or even modern philosophy has reached the shores of philosophical research in the Philippines is surprising. Cullum further notes that the difference with the Philippines and the other colonies of Spain is that Latin America had the benefit of following the intellectual progress of France. ${ }^{6}$ Hornedo notes that the ideas of the French enlightenment and the Philosophe mentality did reach the Philippine shore during the $18^{\text {th }}$ century; however, the thoughts and ideals of this age was restricted to the interest of Spanish gain and was intended for the cultural gain of native Filipinos or Indios. ${ }^{7}$

The introduction of continental and analytic tradition of philosophy came to the Philippines at a later time, specifically, with the exposure of scholars who were fortunate enough to explore modern and contemporary philosophy in foreign universities. Co notes that the sudden shift of scholarship in Scholastic philosophy to more contemporaneous theories and ideas came with the gradual pursuit of foreign education of Filipino scholars

1 Cf. Leonardo Mercado, Elements of Filipino Philosophy (Manila: Divine World University Publications, 1976).

${ }^{2}$ Cf. FlorentinoTimbreza, Pilosopiyang Pilipino (Manila: Rex Bookstore, 1982).

${ }^{3}$ Cf. Leo A. Cullum, "Notes for a History of Philosophy in the Philippines," in Philippines Studies, 7:4 (1959).

${ }^{4}$ Ibid., 456.

${ }^{5}$ Ibid.

${ }^{6}$ Ibid., 457.

${ }^{7}$ Florentino Hornedo, "The French Enlightenment and Bourbon Philippines," in Ideas and Ideals: Essays in Filipino Cognitive History (Manila,. University of Santo Tomas Publishing House, 2001), 51.

(C) 2014 Roland Theuas DS. Pada

http://www.kritike.org/journal/issue 14/pada june2014.pdf

ISSN 1908-7330 
in various universities during the period of the early 1950's up to the late 1970 's. ${ }^{8}$ One such scholar, Emerita Quito, introduced Continental philosophy to the Philippines outside the context of scholasticism. Quito notes that as an authentic discourse in philosophy, Filipino philosophy suffers from inadequacy if it were to be compared to the Greek tradition of Philosophy. Quito's commentary gives us an insight on why such is the current state of Philosophy in the Philippines:

What is philosophy? If the classical Greek definition were to be rigorously applied, namely, that philosophy is "the science that studies all things in their ultimate causes and first principles," then there is no philosophy in the Philippine culture. But then, what ought to be philosophy if not the collective mind of a people interacting with its own universe? What should philosophy be if not the attitude of a people toward life and a Supreme Being? What is philosophy (literally, "love of wisdom") if not a people's concerted effort to acquire wisdom in order to live well? This collective mind, this general attitude toward life, this concerted effort to acquire wisdom which I manifest on the popular grassroots level constituted the folk spirit (Volksgeist) of the Filipino and it should (or will) eventually emerge as a formalized philosophy on the academic level. This philosophy is, however, still in the process of formalization. ${ }^{9}$

For Quito, the question of formality has been an issue for scholars that have been seeking a legitimate form of Filipino philosophy. Though Quito does not deny the possibility of coming up with a formal and academically legitimate form of Filipino Philosophy, she also emphasizes the fact that it has to come from a 'grassroot' level to which the discourse is elevated to an academically suitable degree. At this subtle point, the trend towards the search of Filipino philosophy has become divided in how the idea of a "grassroot" philosophy ought to be understood. For some scholars, the idea of a "grassroot" origin of philosophy ought to be taken from ethnic origins, particularly, the linguistic or folk manifestation of philosophical thought through various languages and folk-literature-a path which is

\footnotetext{
8 Alfredo Co, "In the Beginning... A Petit Personal Historical Narrative of the Beginning of Philosophy in the Philippines," in Unitas, 79:3 (2006), 516.

${ }^{9}$ Emerita Quito, The State of Philosophy in the Philippines (Manila, De La Salle University Press, 1979), 10.

(c) 2014 Roland Theuas DS. Pada

http://www.kritike.org/journal/issue 14/pada june2014.pdf

ISSN 1908-7330
}

$(\mathrm{Cc}) \mathrm{BY}$-NC 
strongly associated with scholars such as Mercado and Timbreza. This path is also prevalently a quasi-ethnological attempt to construct a unified description of Filipino thought through various ethnic practices. A different take on the "grassroot" approach is also prevalent in the works of scholars such as Hornedo, Abulad, Co, and Demeterio. Their take on the idea of what is "grassroot" philosophy in the Philippines, diverges from the methodology of extracting a philosophical system via existing ethnic practices of indigenous people in the Philippines. Suffice to say that for these scholars, the approach towards Filipino philosophy is to utilize the existing discourse of philosophy to make sense or even offer a critique of what Quito would aptly refer to as a Filipino Volksgeist. This path towards an authentic philosophical discourse has been notably productive, producing works that not only depict a kind of "Filipino philosophy"; rather, it proposes a discourse of philosophy itself by Filipinos.

The main contention that I wish to present in this work is that the legitimacy of Filipino Philosophy is not essentially rooted in a unique or even specific kind of philosophy; rather, it is how philosophy is practiced in the productive context of a critique of the concerns of what Quito would refer to as the Filipino Volksgeist. If we were to abide by the notion of philosophy itself, it would be impossible to simply talk about a discourse that has its originary roots in Filipino culture. Philosophy, in general, is a connected series of discourse that has been responding to various cultural traditions in and out of a culture. Isolating our idea of what a "grassroot" philosophy is as an ethnic practice fails the implicit criteria of philosophy as a constantly continuing discourse, which I think is not only detrimental to the idea of what philosophy is, but is also against the idea of philosophy as a discourse. If Filipino philosophy is restricted to the ethnological descriptions of culture, it will diverge from the practice of philosophy as a discourse. Furthermore, philosophy in the context of Filipino philosophy should not look for unitary convergences of ideas, but rather preserve cultural differences in languages, practices, and thought. The stark contrast that I want to raise in this paper is that "grassroot" philosophy need not come from ethnic origins, and that "grassroot" philosophy comes from the continuing effort to use the discourse of philosophy in a localized "grassroot" context. My position is that the ethnological methods of deriving and generalizing a unified kind of Filipino philosophy is limited by its descriptive and constructive tendency to produce a "universalized," 10 reduction of Filipino thought that is neither discursive

${ }^{10}$ Through my readings, I have some misgivings with the agenda of early scholars in Filipino philosophy. Part of this misgiving is the vestigial traces of scholasticism in scholars that construct a "universal" definition of Filipino behavior through the comparison of varying practices in varying cultures within the Philippines. Unifying a "common," "general," or even "universal" kind of Filipino thought is tantamount to saying that the practices that Filipinos have 
nor productive. As a further consequence of Filipino philosophy as a discourse, it is through the constant exercise of philosophical discourse that one is akin to developing the third category, which is the development of a discursive philosophy that originates from Filipino thinkers and engages with the tradition of philosophy as a whole. This is where we find philosophies that are no longer strictly limited to the national or cultural concerns of their own life-world, but rather, are concerned with the discourse of philosophy in general. This is where we find most of the influential and significant ideas that are carried over through the tradition of philosophy, where we find works that are read, not because of their national origin, but because of their effect to philosophy in general.

The notion of what is Filipino is difficult to unify particularly if one is intending to look at ideological and ontological bases for a "universal" definition of Filipino. The cultural practices of Filipinos consistently vary because of ethnic and geographic divisions that characterize the idea of the word "Filipino." If we forget the fact that the word "Filipino" is simply a marker that tells us that a person belongs to a political and geographic area of the Philippines, then we will commit the grave mistake of inventing an illusion of unity of some sorts that may be manipulated for whatever political, economical, and ideological end. A realistic perspective is to look at the notion of shared experiences and concerns that cover the Philippines and the Filipinos in their entirety. In this sense, the idea of what is Filipino will no longer be bound to abstractions constructed for the sake of imagining a stable foundation of identity, which is widespread because of the need of Filipinos to identify themselves with the likes of countries with stable identities. It is through this end that Filipino philosophy can and will find a productive discourse as a philosophy.

I will divide my discussion based on the trajectories mentioned above on how "grassroot" philosophy is manifested through various philosophy scholars in the Philippines. My arbitrary division categorizes Mercado and Timbreza as scholars that belong to the interpretation of "grassroot" philosophy as an ethnic practice; the idea of "grassroot" philosophy in the context of using the philosophical tradition to develop a discourse regarding the cares and concerns of Filipinos can be exemplified through the works of Quito, Hornedo, Abulad, Co, and Demeterio. The scholars that I categorize in these areas are by no means exhaustive; rather, they are examples of how Filipino philosophy is practiced according to my arbitrary categories. My aim is to provide a critique on the methodologies of these scholars so as to legitimize the notion of Filipino philosophy as a discursive activity.

are logically unique because of their essential connection as Filipinos. This kind of perspective draws too much emphasis on coincidences between different cultures and may disregard the possibility that the connection is simply concocted by the scholar's mind.

(C) 2014 Roland Theuas DS. Pada

http://www.kritike.org/journal/issue 14/pada june2014.pdf

ISSN 1908-7330

(cc) BY-NC 


\section{Ethnology as "Grassroot" Philosophy}

\section{Leonardo Mercado and Filipino Philosophy}

The work of Leonardo Mercado is in itself an institution when the thought of translating linguistic practices into a philosophical system comes into mind. Mercado's seminal work in Filipino philosophy is found in Elements of Filipino Philosophy, ${ }^{11}$ a work that tries to compare linguistic practices and behavior in some of the selected dialects in the Philippines with the intention of finding general similarities between some of these dialects as a basis for a unified representation of Filipino thought. Mercado's impressive analysis of some of the Philippine dialects is done through the method of metalinguistic analysis and phenomenology of behavior, ${ }^{12}$ which claim to analyze and compare linguistic practices and verify their existence through phenomenological means. Metalinguistic analysis, according to Mercado, is based on the "assumption that language reflects the thought and somehow determines the outlook of its native speakers."13 The idea is that by looking at the linguistic practices in the Philippines, one will be able to form inferences on the distinct perspectives of reality and non-linguistic data. ${ }^{14}$ Mercado further expands this methodology by stating that these inferences are further developed through the following procedures:

Words or lexemes which have potential basis for philosophical contents are first listed down. Dictionaries of Philippine languages provide a convenient source. Secondly, list the meaning of the words according to their usages. Thirdly, cluster the meanings according [to] groups which are cognitively related. Fourthly, infer the tentative philosophy from clusters. ${ }^{15}$

Mercado's method, as he admits in this work, is his modification of Matthiot's linguistic model, ${ }^{16}$ a model that he specifically constructed for the purpose of analysis of Philippine languages. Mercado's justification for his metalinguistic approach is that the semantic content of some of the languages

\footnotetext{
${ }^{11}$ Cf. Mercado, Elements of Filipino Philosophy.

${ }^{12}$ Ibid., 8-12.

${ }^{13}$ Ibid., 8.

${ }^{14}$ Ibid., 10.

${ }^{15}$ Leonardo Mercado, "Methodologies in Doing Filipino Philosophy," in Karunungan,

${ }^{16}$ Mercado, Elements of Filipino Philosophy, 9.
} 20 (2003), 168-169. 
that he proposes to analyze can shed light on the nature of Filipino philosophy through their similarities in content and meaning. ${ }^{17}$

To support his metalinguistic analysis of some of the Philippine languages, Mercado utilizes another methodological concoction called phenomenology of behavior, in which the semantic content of the linguistic data is verified and supported by observable practices. As a foresight to the possibility of subjective interpretations of the metalinguistic approach, which Mercado sees as a possibility that can occur since the scholastics note that "whatever is received (or perceived) is received according to the nature of the receiver (or perceiver),"18 the phenomenology of behavior serves as a counterchecking mechanism that verifies the correctness of the metalinguistic data. Through this two-fold method, one is able to address a certain kind of hylemorphic unity between matter and essence in terms of Filipino thought, which is inferred through the unity of how linguistic principles are practiced in Filipino behavior, which gives a distinct sense of inductive certainty when the linguistic practice is seen in Filipino behavior. Like a midwife, Mercado notes that through this unity of method, he is able to help in the process of birthing an articulated version of philosophy that is distinctly Filipino. ${ }^{19}$

Among the other methods that Mercado uses, comparative oriental philosophy can also hint at the possibility of acquiring an idea of Filipino philosophy through the similarities of thoughts and behavior from nearby Filipino culture. ${ }^{20}$ Value ranking, as another option for doing Filipino philosophy, takes an ethical perspective in uncovering the moral priorities of Filipino thought based on how Filipinos share a unique arrangement of values, which can interpret a Filipino sense of morality..$^{21}$ Mancenido further notes that Mercado's latest approach in doing Filipino philosophy is to take the perspective of an ethno-philosophy, ${ }^{22}$ as an approach in understanding philosophy in the same context that we understand culture. Mercado remarks that this approach is intended to avoid the sense of rationalism often found in western philosophy, ${ }^{23}$ which is also consistent with his earlier remark in Elements of Filipino Philosophy about the possible danger in contaminating Filipino thought through Western categories. ${ }^{24}$

Mercado's analysis of language and behavior is at its best a difficult and demanding task; the method aims to compare some of the Filipino

\footnotetext{
${ }^{17}$ Ibid., 10.

${ }^{18}$ Ibid., 11.

${ }^{19}$ Ibid., 11.

${ }^{20}$ Mercado, Methodologies in Doing Filipino Philosophy, 171.

${ }^{21}$ Ibid., 172.

${ }^{22}$ Marella Ada V. Mancenido, "Filipino Philosophy According to Mercado and Timbreza," in Dalumat, 1:1 (2010), 81.

${ }^{23}$ Leonardo Mercado, Filipino Thought (Manila: Logos Publications, Inc., 2000)

${ }^{24}$ Mercado, Elements of Filipino Philosophy, 10.

(C) 2014 Roland Theuas DS. Pada

http://www.kritike.org/journal/issue 14/pada june2014.pdf

ISSN 1908-7330
}

$(\mathrm{Cc}) \mathrm{BY}$-NC 
languages and their usage to find similarities in which one can infer common thoughts and philosophical perspectives. One particular concept that is of interest is how Mercado interprets the varying notions of interiority in some of the Philippine languages. Using the words loob, buot, and nakem (respectively taken from Tagalog, Visayan, and Ilocano dialects), Mercado compares them and highlights the general similarities that can be observed in their respective dialects. ${ }^{25}$ The comparison is extensive and to some extent exhaustive given the context of learning the three highlighted languages. Mercado finds the common themes of debt of gratitude or utang na loob as a common observable behavioral trait among Filipinos; ${ }^{26}$ along this line of thought, Mercado further verifies the common theme of holistic unity in the idea of selfhood through the unitary use of loob, buot, and nakem as reference to the self from the three dialects mentioned. ${ }^{27}$

Mercado uses this methodology to further discuss a notion of Filipino philosophy found in the common uses of these languages, from the nature of thought, social practices, politics, and even ethics. I do not intend to dispute Mercado's findings in this paper; rather, my objective is to raise some critical questions on how his method arrives at a notion of Filipino philosophy. In reading Mercado's works, one has the feeling that the search for Filipino philosophy is intended to fill in a lacking sense of Filipino identity due to its varying cultural and regional differences. Mercado aims at reconstructing ethnological data to find unities or even universalities to which one can fully articulate a Filipino sense of culture and identity. Unfortunately, when one looks at Mercado's analyses, the tendency of his work is reductive insofar as his analyses revolves only under the study of representative dialects that, for him, are already sufficient to mark a "Filipino" identity. Although he is aware of this limitation, ${ }^{28}$ the scope of generalization from three "general" Filipino dialects (namely, Tagalog, Ilocano, and Visayan) does marginalize the few dialects that may have also contributed to Filipino thought. Furthermore, a holistic interpretation falls short in this project since the source of data is lacking and may have problems in asserting a generalized or universalized sense of what is "Filipino." To add to this, there is a certain sense of ambiguity when Mercado tries to assert that tools and methods in evaluating Filipino philosophy ought to be done in a non-Western category. This problem is further complicated by the fact that Mercado often cites Western philosophies to found most of his arguments; the scholastic tone even furthers the irony of his aversion to Western theories. I think that his shift to ethno-philosophy in

${ }^{25} \mathrm{Ibid} ., 65$.
${ }^{26} \mathrm{Ibid}$.
${ }^{27} \mathrm{Ibid} ., 66$.
${ }^{28} \mathrm{Ibid} .$,

(c) 2014 Roland Theuas DS. Pada

http://www.kritike.org/journal/issue 14/pada june2014.pdf

ISSN 1908-7330 
the light of how Eastern philosophies are read and discoursed is how Mercado acknowledges this problem.

Another observation that I can comment on is that Mercado's idea of Filipino Philosophy is ahistorical in a sense that it neglects the significant influence of Colonial forces that have shaped and affected Filipino behavior. One glaring omission is Mercado's lack of reference to Spanish and American influences in Filipino thought since they are often referred to as an afterthought. ${ }^{29}$ Reading Mercado's work has given me the impression that the context of the dialects in his analyses is as if they were languages that sprung out of nothing. The linguistic analyses fail to specify whether the linguistic and behavioral analyses are under diachronic or synchronic contexts as they fail to give the right sense of whether these linguistic and behavioral data are evolving through time or are specific to a certain period of time.

My final criticism of Mercado's methodology is that along with the blurry distinction between diachronic and synchronic observation of language, Mercado fails to articulate the role in which subjectivity is able to shape linguistic and behavioral practices in Filipinos. I think that Mercado wants to create a metaphysical or ontological foundation on which the concept of a Filipino philosophy can be defined in clear and sterling Scholastic definitions, which seems to be achievable in the context of his work; however, one has to be aware of the consequences of such endeavor. Such ideal can persists, and will only persist in the mind of its author as it fails to become adequate (or even worse, become a stereotype or a racial form of discrimination) in the reality that it tries to represent.

Florentino Timbreza: Experiencing the Filipino through the FolkThoughts and Expression

FlorentinoTimbreza follows a similar approach of constructing Filipino philosophy through the expressions of varying dialects and practices by some Filipino ethnicities. Like Mercado, Timbreza's argument on the nature of Filipino philosophy is based on how some Filipinos are able to enact a kind of wisdom or sagely practice in everyday life. ${ }^{30}$ Timbreza directly addresses a criticism raised by Quito on the status of philosophy in the Philippines by stating that:

...hindi naman kalabisan kung sasabihin ang mga Pilipino ay mayroon ding sariling Weltanschauung at sangkadiwaan

\footnotetext{
${ }^{29}$ The mention of Colonial influence is often added as an afterthought; Mercado rarely mentions them in terms of their linguistic contributions. Spain is often mentioned only on the context of how they were able to contribute to some of the religious practices in Filipino thought.

30 Timbreza, Pilosopiyang Pilipino, 3.

(C) 2014 Roland Theuas DS. Pada http://www.kritike.org/journal/issue 14/pada june2014.pdf

ISSN 1908-7330
}

(cc) BY-NC 
pilosopiya sa buhay na napapaloob sa kanilang kaalamangbayan. Ang huli ay binubuo ng kanilang mga alamat, tula, epiko, awit, paniwala, bugtong, ritwal, ugali, katutubong sayaw at mga kasabihan at salawikain. Makikita sa mga ito hindi lamang ang kanilang mga kuwentong-bayan at mga katutubong kaugalian kundi lalung-lalo na ang kanilang paghahaka at mga pananaw na siyang bunga ng kanilang pagmamasid at angking karanasan. Kaya't ang Pilipino ay mayroon ding natatanging pilosopiya tungkol sa masalimuot na kalagayan ng buhay-tao.

...it is not too much to say (or claim) that the Filipinos have their own Weltanschauung and unified philosophy in life that expresses their own national-thought. The latter is composed of mythology, poetry, epics, songs, beliefs, riddles, rituals, attitudes, folk-dance, folksayings and proverbs. It can be seen that these are not simply the regional stories and indigenous behavior; rather, they are important reflections and perspectives based on observation and experience. That is why the Filipino has its own unique philosophy about its own complicated condition of human life. ${ }^{31}$

Timbreza here argues that the cultural products of Filipinos are enough sign that Filipinos are capable of doing philosophy, though this translates in the similar vein that philosophy is understood in a cultural context as much as Eastern philosophy is regarded as a legitimate philosophy in a Western context. Timbreza further argues that it is through the unique perspectives and cultural inclinations that Filipinos have an experience of what is Filipino. Among these manifestations of culture and organized thought, Timbreza opts to focus his research on salawikains, which roughly translates as folk-sayings or proverbs. ${ }^{32}$ Timbreza likens the transmission of these proverbs or folk-sayings to philosophy; ${ }^{33}$ they are not only vehicles through which Filipinos are able to pass the experiences of the people from one generation to another, but are also ways in which wisdom is preserved and organized as a kind of cultural practice. Philosophy then is likened to adages, stories, and proverbs from which Filipinos are able to draw rich reflections on various topics such as ethics, aesthetics, politics, and religion,

\footnotetext{
${ }^{31}$ Ibid., 3. [The English version is the author's own translation]

32 Ibid., 4.

${ }^{33}$ Ibid., 5.
} 


\section{PROBLEMS OF FILIPINO PHILOSOPHY}

which could be likened to the similar strand of philosophies from Eastern cultures, much as we draw lessons from the Tao Te Jing or a Zen haiku.

This methodology heavily relies on Timbreza's wide array of folksayings that come from various dialects. The list of dialects from which the proverbial wisdom of folk-sayings are drawn include Tagalog, Ilokano, Ivatan, Pampanggo, Panggasinensi, Ibanag, Bicolano, Igorot, Cebuano, Boholano, Bisaya, Tiruray, Tausug, Maranao, Maguindanao, Aklano, Bukidnon, Sugbuanon, Zambaleno, Romblomanon, Kinaraya, Ilonggo, Waray, and Kalinga-Banao. This impressive range of dialects is arranged thematically so that one can draw a unified theme based on samples of these dialects that contribute to what can be surmised as folk-philosophy. ${ }^{34}$ There is, however, an issue of how Timbreza was able to document the source of his folk-sayings. Unlike Mercado, who has painstakingly cited and documented the source of his ethnological data, Timbreza is unclear about how these folk-sayings were collected. One can surmise that since these folk-sayings are quite common in every regional dialect, the collection may have been taken from informal sources. But then again, such could have been remedied with at least a simple anthropological method of documenting the names of the sources, the dates and places from which this data have been gathered, and the nature of the sources to put them in a position of credibility.

Regardless of this omission of documentation, Timbreza's interpretation of folk-sayings provides a very interesting and entertaining insight on folk-culture akin to how most Eastern philosophies are read in the tradition of Indian and Chinese literature. What is likewise laudable is Timbreza's use of the Philippine's official language in writing philosophy; this is a feat that is considerable as the practice itself is done only by a handful of scholars in the academe. Timbreza's thematics in doing Filipino philosophy covers similar areas as Mercado's; the difference, however, in their approach is that Timbreza's analysis is not linguistic but hermeneutic and experiential.

As a "grassroot" philosophy, Timbreza's is also able to fulfill Quito's criteria of tapping into a volksgeist or folk-spirit into which one can claim an existence of Filipino philosophy. However, if we were to look at the requirement as to whether his analyses qualify as a legitimate kind of philosophy in the Western tradition, Timbreza's work does not qualify in a sense of an organized system of discourse. Again, just like Mercado, Timbreza's attempt is to present and somewhat systematize a sense of Filipino thought. But given the kind of material that they want to use for the creation of a legitimate Filipino philosophy, the trajectory of their work will

${ }^{34}$ Ibid., 8.

(C) 2014 Roland Theuas DS. Pada

http://www.kritike.org/journal/issue 14/pada june2014.pdf

ISSN 1908-7330

$(\mathrm{cc}) \mathrm{BY}-\mathrm{NC}$ 
end up as a kind of ethnological description and interpretation of Filipino culture.

Perhaps with a stronger bent on anthropological methods, their research can be used as a critical form of ethnology. By refining the methods in which they gather and interpret their data, their work can be useful in underlining the causes and probable effects of Filipino culture on contemporaneous topics. A general criticism can be raised in Mercado and Timbreza's concern for creating a Filipino philosophy, that is, the issue of how Filipino philosophy should be presented as an organized system of thought should not be the primary area of concern. How one can produce a healthy discourse by diagnosing existing problems and pathological tendencies from Filipino culture is a more pressing issue, given the fact that the Philippines, just like any other nation, suffers from its own culturallyinduced pathological problems. Aside the concern of presenting a unified and organized system of thought, Filipino philosophy in the light of Mercado and Timbreza's methods will also benefit from stronger ties with their ethnology and with the historicity of their ethnological data. One can, for example, provide a deeper linguistic and behavioral analysis of the effects of Colonization in the context of Filipino territorial behavior or "sakop" system, and perhaps connect a strong critical analysis as to how it becomes epidemic due to the scarcity of ownership of land. These areas of concern are now the current trend and concern of the other interpretation of "grassroot" philosophy in the context of Filipino philosophy.

\section{"Grassroot" Philosophy and Critique}

\section{Emerita Quito and the Paradigm Shift in Filipino Philosophy}

Quito's reputation as a Filipino philosopher has been a topic of many papers and research in local Filipino philosophy publications. Quito is credited as one of the early secular philosophers in the Philippines that bought contemporary continental philosophy to Philippine shores. Co credits Quito as one of the pioneers of the second stage of Filipino philosophical scholarship ${ }^{35}$ with its bent on moving beyond the Hispanic tradition of scholasticism for theological studies. Quito's contribution to the discourse of philosophy is balanced in terms of her gloss on both Eastern and Western sides; however, it is notable that her contribution to Filipino philosophy comes from her analysis of its status in the Philippines.

${ }^{35}$ Alfredo Co, "Doing Philosophy in the Philippines: Fifty Years Ago and Fifty Years from Now," in Karunungan, 21 (2004), 7.

(C) 2014 Roland Theuas DS. Pada

http://www.kritike.org/journal/issue 14/pada june2014.pdf

ISSN 1908-7330 
Quito's seminal work in her critique of Filipino philosophy or, rather, her critique of the state of philosophy in general may be seemingly anachronistic as a point of interest in this work. However, we must understand that Quito's arguments were a big influence in developing an interest in Filipino philosophy as an area for scholarship. Quito classifies various approaches that can be done in the search for a Filipino philosophy. She notes that one can do Filipino philosophy in an academic, grassroot, and indigenous approach. ${ }^{36}$ The academic approach refers to how the usual form of research is conducted in a university setting such as papers, articles, essays, monographs, and books. Quito begrudgingly criticizes the Philippines for its heavy bent on Thomistic philosophy ${ }^{37}$ in the academe, and this criticism is constantly emphasized throughout the rest of her work. ${ }^{38}$ My take on her mention of the grassroot approach is somewhat a combination of academic discussion of philosophy geared towards localized concerns and issues in the Philippines. ${ }^{39}$ For this matter, the indigenous approach, as we can derive from Mercado and Timbreza, is one way of generating philosophical interest in the local scene, which is helpful if we want to develop a stronger grassroot tradition. The caveat for this, however, is that the grassroot approach should expand and exponentially so as to reach academic legitimacy; in other words, grassroot and indigenous philosophy can only reach academic legitimacy once it begins to participate in the long tradition of discourse in philosophy. Another pioneering approach in this work is Quito's bibliographic analysis of philosophical works in the Philippines. ${ }^{40}$ Though limited to M.A. theses and dissertations, this collection of data is helpful in analyzing trends, strengths, and weaknesses in philosophical research. This agenda is also carried over by Gripaldo's comprehensive and critical bibliography on Filipino philosophy.41 Sadly, this bibliographical research has been discontinued since 2002; to this date, it is already 12 years behind for update.

Quito's tendency in her critique of the state of philosophy in the Philippines lingers on Eurocentric perspective as she strongly compares the Philippine academe to European universities.42 Quito's Eurocentrism, however, has its own basis. For one, if the philosophical scene in the

\footnotetext{
${ }^{36}$ Quito, The State of Philosophy in the Philippines, 9-10.

${ }^{37}$ Ibid., 9.

${ }^{38}$ For more about these, see the following pages on The State of Philosophy in the Philippines, 34, 38, 43, 45, 51, and 57. Quito, in these pages, is very critical of Thomistic philosophy as a prevalent system in her time; specifically, the bent of her ire is often placed against the University of Santo Tomas.

${ }^{39}$ Ibid., 12-13.

${ }^{40}$ Ibid., 59-104.

${ }^{41}$ Cf. Rolando Gripaldo, Filipino Philosophy: A Critical Bibliography [1774 - 1992; $1993-$ 1997;1998-2002] (Manila: De La Salle University, 2004).

${ }^{42}$ Ibid., 10.

(C) 2014 Roland Theuas DS. Pada

http://www.kritike.org/journal/issue 14/pada june2014.pdf

ISSN 1908-7330
}

$(\mathrm{Cc}) \mathrm{BY}$-NC 
Philippines wants to grow as a strong academic tradition, it has to achieve legitimacy through academic achievement through rigid, thorough, and creative production of philosophical ideas. Though that ideal is quite nearer to the current trend of publications in philosophy in the Philippines, what is still present in Quito's comparison is the lack of critical rapport with the conditions of Philippine life. ${ }^{43}$ Perhaps what Quito is trying to propose is the same kind of political activism that transcends the academic importance of philosophy to real and material conditions in the same manner that we can observe during the political upheaval of 1968 in France. This perspective was later on picked up by F.P.A Demeterio III, a much more recent scholar in the area of Filipino philosophy.

\section{Florentino Hornedo and the Multidisciplinary Nature of Filipino Philosophy}

It is surprising that amidst all the interest in the revival of folkliterature and Filipino philosophy, there seems to be little mention of Hornedo's works. Perhaps through the strict academic segregation of disciplines (which Hornedo is able to broadly encompass), little attention has been brought to Hornedo's engagement with Filipino culture and philosophy. Hornedo does not employ a single methodology in terms of how he approaches Filipino thought; rather, he employs a very broad and extensive multidisciplinary approach to Filipino thought and culture. As a trained ethnographer and ethnologist, his works offer a fecund foundation for a "grassroot" kind of Filipino philosophy. A particular product of this training gives Hornedo a critical eye and very sensible conclusions in his work. Here is an exacting comment that may as well apply to Filipino philosophy inasmuch as it applies to Filipino literature.

Two opinions concerning Philippine literary theory (and by consequence criticism) have been on the forefront for some time now. One we may call the "universalistic theory" and the other the "nationalistic theory." The first claims that literary theory and the standards by which literary quality is to be judged are valid everywhere in the globe at all times. The second says that every culture is essentially unique, and the qualities that characterize it, and consequently the standards by which it should be judged, are also unique and particular to each nation. But to the present, Filipino literary historians and

${ }^{43}$ Ibid., 40.

(C) 2014 Roland Theuas DS. Pada

http://www.kritike.org/journal/issue 14/pada june2014.pdf

ISSN 1908-7330 
theorists have yet to come up with nationally valid generalizations about the "unique" properties of Filipino literature because the country still lacks a fully comprehensive view of Filipino literature. English and Spanish writing in the country are well circumscribed in time, and their volume is manageable. Of the vernacular literatures, Tagalog is the best covered. Cebuano, Iloko, Pampango, Ilongo, and a few others are now receiving more attention. But our knowledge of the ethnic literatures, though substantial, is still fragmentary, and the entire mosaic cannot yet be seen in total perspective neither of time nor of space. ${ }^{44}$

Given as a contrast to the views of Mercado and Timbreza, Hornedo delimits his ethnological research on specific cultures due to the fact that it is impossible to produce an "all-encompassing" perspective of what it is to be a Filipino. Hornedo's strong connections to ethnography, ethnology, and literature provide him a very distinct position in the scholarship of Filipino philosophy as his conclusions in works are usually specific to a regional culture in the Philippines. Moreover, he is also aware of the historical forces through which behavior and thought are manifested by Filipinos; for example, he distinguishes "traditional" from "cosmopolitan" in the sense of the word "Filipino." 45 Moreover, Hornedo's research is mostly substantiated by strong anthropological data that are derived first-hand as product of his research. Though prudent in his declaration of a broad concept of an idea of what is a "Filipino," Hornedo provides a much more rigid use of anthropological data, objective contextualization of history, and critical perspective, which have not been a strong point of Mercado and Timbreza's work. Hornedo's work not only brings a critical view of Philippine history; he is also able to tie down this historicity with contemporary issues and concerns. Creating a connection between folk-satire and the Marcos regime ${ }^{46}$ brings about a better contextualization of folk-sayings in the way that it is used in a historical context. Likewise, a critical look at regional divisions in the Philippines in the form of ethnic conflict ${ }^{47}$ can enlighten a researcher in Filipino philosophy as to why stereotypes are common within the cultural context of the Philippines.

\footnotetext{
${ }^{44}$ Florentino Hornedo, Laji: An Ivatan Folk Lyric Tradition (Manila: University of Santo Tomas Publishing House, 1997), xiii.

${ }^{45}$ Florentino Hornedo, Pagmamahal and Pagmumura (Quezon City: Office of Research and Publication, Ateneo de Manila University, 1997), 1.

${ }^{46}$ Hornedo, Ideas and Ideals: Essays in Filipino Cognitive History, 221.

${ }^{47}$ Cf. Hornedo, Pagmamahal and Pagmumura, 40.

(C) 2014 Roland Theuas DS. Pada

http://www.kritike.org/journal/issue 14/pada june2014.pdf

ISSN 1908-7330
}

(cc) BY-NC 
The research output of Hornedo in philosophy is not strictly limited to Filipino culture and ideologies; there is also a significant amount of literature in his publication that engages in a productive discourse in philosophy. To name one, his treatise on freedom ${ }^{48}$ produces a discourse that engages the scholastic, phenomenological, and existential traditions in philosophy regarding the freedom and autonomy of persons. Notably, this work has drawn inspiration from the time of protests and demonstrations, which preludes the Martial Law era in the Philippines. ${ }^{49}$ Moreover, Hornedo also contributes to philosophical themes in contemporary literature ${ }^{50}$ as well as various essays in Postmodernism and Poststructuralism. ${ }^{51}$

\section{F.P.A. Demeterio and Critical Filipino Philosophy}

Demeterio has been an active scholar in Filipino philosophy; his contribution to the scene of this research area is both significant and productive. His participation in the critique of methodologies in Filipino philosophy is fundamental in our understanding of a critical Filipino ideology insofar as he engages in Quito's criticisms as well as localizing the discourse of the social sciences and critical philosophy to the Philippine context. Demterio's early response to Quito addresses and revitalizes the considerable failures of Filipino philosophy. Demeterio argues that Quito's defeatist attitude towards the state of Filipino philosophy is brought about by a distorted perspective of theoretical paradigms, which he borrows from Kuhn's notion of Scientific Revolutions. ${ }^{52}$ Instead of blaming and chastising our colonial roots and their mis-development of Filipino philosophy, Demeterio suggests a "pro-active" acceptance of this condition by which we can continue to refine existing paradigms and methodologies.53 By engaging Philippine reality through the creative use of theoretical paradigms, be it philosophical, sociological, or anthropological, Demeterio concludes that the lack of organised history, tradition, or academic output in Filipino philosophy will eventually be developed..$^{54}$

${ }^{48}$ Cf. FlorentinoHornedo, The Power To Be: A Phenomenology of Freedom (Manila: University of Santo Tomas Publishing House, 2000).

${ }^{49} \mathrm{Ibid}$., ix.

${ }^{50} \mathrm{Cf}$. Florentino Hornedo, Pagpapakatao and Other Essays in Contemporary Philosophy and Literature of Ideas (Manila: University of Santo Tomas Publishing House, 2002).

${ }^{51}$ Cf. Florentino Hornedo, "Free Fall: Postmodernism," in Ad Veritatem, 5:1 (October 2005), 77-85.

52 F.P.A. Demeterio III, Re-Reading Emerita Quito's Thoughts Concerning the Underdevelopment of Filipino Philosophy, in Diwatao, 1:1 (2001), $<$ http://www.geocities.ws/philodept/diwatao/emerita_quito.htm>.

${ }^{53}$ Ibid.

${ }^{54} \mathrm{Ibid}$.

(c) 2014 Roland Theuas DS. Pada

http://www.kritike.org/journal/issue 14/pada june2014.pdf

ISSN 1908-7330 
Following this trail, Demeterio provides several analyses of how the paradigm of Filipino philosophy could be improved. Demeterio proposes a cognitive anthropology of Filipino culture as a way of developing a legitimate, discursive, and productive Filipino philosophy. ${ }^{55}$ Demeterio describes the progress of the discourse of Filipino philosophy in four phases, namely: (1) First Colonial Phase-the unchallenged predominance of Thomism, (2) Second Colonial Phase-the influx of foreign and contemporary theories brought by foreign educated Filipino scholars, (3) Early Indigenization - the question of existence and progress of Filipino philosophy as well as its description of Filipino identity, and lastly, (4) Late Indigenization-the distantiation of Filipino scholars from the early indigenization phase. ${ }^{56}$ The distantiation that Demeterio mentions in these phases is perhaps associated with the more contemporaneous view that identity is not simply a matter of drawing a metaphysical or ontological definition of "Filipino" that contemporary continental philosophy is well aware of. Identity is not simply an issue of definition; for contemporary theories such as deconstruction and critical theory, identities are relational and are dependent ideological perspectives. To offer an alternative to a metaphysical or ontological definition of Filipino identity, Demeterio proposes in his early works the use of Cognitive Anthropology as a way of utilizing existing sociological, cultural, and anthropological paradigms to overcome the early indigenization phase.

Demeterio's application of cognitive anthropology is seen in a variety of applications in his work; one particular essay to note applies cultural critique of postmodernity in the Philippine context, in which Demeterio declares the Philippines as a pre-modern culture. ${ }^{57} \mathrm{He}$ also addresses the hegemonic state of Filipino culture due to its diversity and multicultural context. 58 Like Hornedo,59 Demeterio argues that the recognition of multiculturalism and differences between regions is key to building sustainable relations in our nations rather than just simply create an illusion of unity or similarities. ${ }^{60}$ To add to this, various paradigms have been used in

\footnotetext{
${ }^{55}$ F.P.A. Demeterio III, Cognitive Anthropology and the Unfinished Agenda of the

Early Indigenous Phase of Filipino Philosophy, in Diwatao (2001), $<$ http://www.geocities.ws/philodept/diwatao/cognitive_anthropology.htm>.

${ }^{56} \mathrm{Ibid}$.

${ }^{57}$ F.P.A. Demeterio III, “Our Premodernity and Their Tokens of Postmodernity: Reflections on the Philippine Condition." Date Accessed: August 14, 2013, $<$ https://sites.google.com/site/feorillodemeterio/Premodernity\%20Postmodernity.pdf?attredirec $\mathrm{ts}=0>$.

58 F.P.A. Demeterio III, “Ang Balangkasang Multikulturalismo at ang Pagbuong Bansang Pilipino," in Lumina, 20:2 (2009), 6.

${ }^{59}$ Hornedo, Pagmamahal at Pagmumura, 48.

${ }_{60}$ Demeterio, “Ang Balangkasang Multikulturalismo at ang PagbuongBansang Pilipino," 17.
}

(C) 2014 Roland Theuas DS. Pada

http://www.kritike.org/journal/issue 14/pada june2014.pdf

ISSN 1908-7330

(cc) BY-NC 
the context of Filipino philosophy, and cultural studies have been made. To name a few, Demeterio provides a critique of the model of democracy in the Philippines, ${ }^{61}$ and some localization of philosophical and sociological theories in the Filipino context, namely that of Rorty, ${ }^{62}$ the hermeneutics of Schleiermacher and Dilthey, ${ }^{63}$ dialectical hermeneutics, ${ }^{64}$ and Lyotard. ${ }^{65}$ This, of course, is a small bibliographical sample of Demeterio's contribution to Filipino philosophy and this by all means does not serve as a comprehensive bibliography.

\section{Analyses and Concluding Remarks}

In the methodologies and analyses of various Filipino philosophers that I have presented, one can be led to a conclusion that the trend towards Filipino philosophy as a discourse is shifting its interest to more productive topical concerns. The usefulness of philosophy as a tool for methodological understanding of culture is clear when it loses the character of simply establishing Filipino identity as a cultural edifice. A point that I want to emphasize in this paper is that identity building is not a task that should be taken by philosophy as it is a tradition that relies on continuous critical discourse. If the desire is to take a descriptive stance, a stronger ethnological methodology becomes necessary. These problems are seen in the methodology of Mercado and Timbreza, as they seem to have lost some critical distance in their pursuit of creating a unified notion of Filipino through philosophy.

Following Quito's analyses, we can glean that the very core of philosophy itself is rooted in its discursive nature. Demterio's refinements and response to Quito further reinforces the idea that philosophy need not be an edifice that represents Filipino intellectual achievement, for as we know, philosophy did not simply materialize in a matter of decades in Greek, German, and French culture. We know for a fact that these cultures have tried to continually engage in intellectual discourse over issues that have touched their cultures. Perhaps over time, historians will regard Filipino philosophy in that same category. As I like to think about this possibility, I simply dismiss

${ }^{61}$ F.P.A. Demeterio III, “Ang Demokratikong Sistema at ang mga Modelong Pamumuno sa Pilipinas," in Kritike, 4:1 (2010).

${ }^{62}$ F.P.A. Demeterio III, "Some Useful Lessons from Richard Rorty's Political Philosophy for Philippine Postcolonialism," in Kritike, 2:2 (2008).

${ }^{63}$ F.P.A Demeterio III, "Ang Hermenyutika nina Schleiermacher at Dilthey bilang Batayang Teoretikal sa Araling Pilipino," in Kritike, 5:1 (2011).

${ }^{64}$ F.P.A Demeterio III, "Ang mga Dialohikal na Hermenyutika nina Heidegger, Bultman, at Gadamer Bilang Batayang Teoretikal sa Araling Filipino," in Kritike, 6:1 (2012).

65 F.P.A. Demeterio III, "Ang Pilosopiya ni Jean-Francois Lyotard bilang BatayangTeoretical sa Araling Pilipino," in Kritike, 7:2 (2013). 
it as a problem for historians and scholars to ponder. What is important is that philosophy actively remains productive in pressing matters that require critical intellectual insights. In a recent work, Demeterio further argues that there are four types of work in Filipino philosophy that are no longer productive or relevant in an academic setting. ${ }^{66} \mathrm{He}$ argues the following: (1) Grassroot/Folk Philosophy is not a philosophy as such but a kind of collective mentality; (2) Lectures on Scholasticism/Thomism do not contribute to the textual propagation of Filipino philosophy; (3) Lectures on foreign systems again do not provide the necessary textual propagation for Filipino philosophy; and (4) Non-Academic discourse on critical philosophy is not entirely academic because it lacks discoursive control from the academe. ${ }^{67}$ Demeterio's intention in this paper is to further look into the salient aspects of research and development of the discourse of Filipino philosophy as an academic discipline that is both socially relevant and at the same time sustainable in its discourse. The lack of textual propagation and informality on the part of the four discourses mentioned above cause the failure to critically engage their own discourse akin to most philosophical traditions. It is not to say that folk thought, the analysis of native Filipino languages, and the contemplation of popular ideologies are not fit for the analyses of academic philosophers. My opinion in this matter is to leave such ruminations to the hands of academics that are trained to deal with sociological, anthropological, and ethnological matters.

As a further note, my aim at this juncture is to highlight two exemplar Filipino scholars that are beneficial to the discourse of Filipino philosophy, namely Hornedo and Demeterio. These scholars have broken the ice in the practice of pure-philosophy by giving it a multi-disciplinary approach. By highlighting some of their works, I hope to draw in scholars that are interested in the study of Filipino culture not only in the context of philosophy but as a combined discipline of anthropological, literary, historical, and sociology. While it is of interest to point out the philosophical orientation of the works that Hornedo and Demeterio present, it is also of interest to know that their exemplary scholarship is also a product of being exposed other disciplines that complement and strengthen their insights. If we were to go back and compare the ideal context of Quito's European academic standards for philosophy, I do not think that we are far from achieving such goal with Hornedo and Demeterio.

To conclude this paper, I find that the "grassroot" element of Filipino culture is a useful starting point Filipino philosophy. By engaging in a healthy and creative critique, Filipino philosophy will continue to exist as a cultural,

${ }^{66}$ F.P.A. Demeterio III, "Assessing the Development Potentials of Some Twelve Discourses of Filipino Philosophy," in Philipiniana Sacra, XLIX:147 (May - August 2014), 189.

${ }^{67}$ Ibid., 191.

(C) 2014 Roland Theuas DS. Pada

http://www.kritike.org/journal/issue 14/pada june2014.pdf

ISSN 1908-7330

(cc) BY-NC 
intellectual, and academic tradition in its own right. The security of a future for philosophy does not lie in its monuments, and whether philosophy is dead or is about to be born in our culture is irrelevant, for as long as we continue to acknowledge its discourse and build upon it, our own discourse philosophy will prevail.

$$
\begin{array}{r}
\text { Department of Philosophy } \\
\text { Research Center for Culture, Education and Social Issues } \\
\text { The Graduate School } \\
\text { University of Santo Tomas, Philippines }
\end{array}
$$

\section{References}

Co, Alfredo, "Doing Philosophy in the Philippines: Fifty Years Ago and Fifty Years from Now," in Karunungan, 21 (2004). "In the Beginning... A Petit Personal Historical Narrative of the Beginning of Philosophy in the Philippines," in Unitas, 79:3 (2006).

Cullum, Leo A., "Notes for a History of Philosophy in the Philippines," in Philippines Studies, 7:4 (1959).

Demeterio, F.P.A. III, "Ang Balangkasang Multikulturalismo at ang Pagbuong Bansang Pilipino," in Lumina, 20:2 (2009).

"Ang Demokratikong Sistema at ang mga Modelong Pamumuno sa Pilipinas," in Kritike, 4:1 (2010).

"Ang Hermenyutika nina Schleiermacher at Dilthey bilang Batayang Teoretikal sa Araling Pilipino," in Kritike, 5:1 (2011).

"Ang mga Dialohikal na Hermenyutika nina Heidegger, Bultman, at Gadamer Bilang Batayang Teoretikal sa Araling Filipino," in Kritike, 6:1 (2012).

"Ang Pilosopiya ni Jean-Francois Lyotard bilang BatayangTeoretical sa Araling Pilipino," in Kritike, 7:2 (2013).

, "Assessing the Development Potentials of Some Twelve Discourses of Filipino Philosophy," in Philipiniana Sacra, XLIX:147 (May - August 2014).

"Our Premodernity and Their Tokens of Postmodernity: Reflections on the Philippine Condition." Date Accessed: August 14, 2013,

$<$ https://sites.google.com/site/feorillodemeterio/Premodernity\%20Po stmodernity.pdf?attredirects $=0>$.

"Some Useful Lessons from Richard Rorty's Political Philosophy for Philippine Postcolonialism," in Kritike, 2:2 (2008).

Cognitive Anthropology and the Unfinished Agenda of the

Early Indigenous Phase of Filipino Philosophy, in Diwatao (2001),

(c) 2014 Roland Theuas DS. Pada

http://www.kritike.org/journal/issue 14/pada june2014.pdf

ISSN 1908-7330 


\section{PROBLEMS OF FILIPINO PHILOSOPHY}

$<$ http://www.geocities.ws/philodept/diwatao/cognitive_anthropolo gy.htm>.

Re-Reading Emerita Quito's Thoughts Concerning the Underdevelopment of Filipino Philosophy, in Diwatao, 1:1 (2001), $<$ http://www.geocities.ws/philodept/diwatao/emerita_quito.htm>.

Gripaldo, Rolando, Filipino Philosophy: A Critical Bibliography [1774 - 1992; 1993-1997;1998-2002] (Manila: De La Salle University, 2004).

Hornedo, Florentino, "Free Fall: Postmodernism," in Ad Veritatem, 5:1 (October 2005).

"The French Enlightenment and Bourbon Philippines," in Ideas and Ideals: Essays in Filipino Cognitive History (Manila,. University of Santo Tomas Publishing House, 2001).

Laji: An Ivatan Folk Lyric Tradition (Manila: University of Santo Tomas Publishing House, 1997)

Pagmamahal and Pagmumura (Quezon City: Office of Research and Publication, Ateneo de Manila University, 1997).

, Pagpapakatao and Other Essays in Contemporary Philosophy and Literature of Ideas (Manila: University of Santo Tomas Publishing House, 2002).

The Power To Be: A Phenomenology of Freedom (Manila: University of Santo Tomas Publishing House, 2000).

Mancenido, Marella Ada V., "Filipino Philosophy According to Mercado and Timbreza," in Dalumat, 1:1 (2010).

Mercado, Leonardo, "Methodologies in Doing Filipino Philosophy," in Karunungan, 20 (2003).

Elements of Filipino Philosophy (Manila: Divine World University

Publications, 1976). Filipino Thought (Manila: Logos Publications, Inc., 2000).

Quito, Emerita, The State of Philosophy in the Philippines (Manila, De La Salle University Press, 1979).

Timbreza, Florentino, Pilosopiyang Pilipino (Manila: Rex Bookstore, 1982).

(C) 2014 Roland Theuas DS. Pada

http://www.kritike.org/journal/issue 14/pada june2014.pdf

ISSN 1908-7330

$(\mathrm{cc}) \mathrm{BY}-\mathrm{NC}$ 